\title{
A new species of Octaspidiotus (Hemiptera, Diaspididae) from China
}

\author{
Jiufeng Wei', Qing Zhao' \\ I College of Agriculture, Shanxi Agricultural University, Taigu, Shanxi, China \\ Corresponding author: Qing Zhao (zhaoqing86623@163.com)
}

Academic editor: R. Blackman | Received 20 April 2016 | Accepted 29 June 2016 | Published 14 July 2016

http://zoobank.org/00A43EB3-3482-42C5-8073-9364D2C4D33A

Citation: Wei J, Zhao Q (2016) A new species of Octaspidiotus (Hemiptera, Diaspididae) from China. ZooKeys 605: 83-89. doi: 10.3897/zookeys.605.8944

\begin{abstract}
Adult females of a new species of armored scale insect, Octaspidiotus shanghaiensis sp. n. are described and illustrated from specimens collected in China. A key is provided for the all described species of Octaspidiotus.
\end{abstract}

\section{Keywords}

Taxonomy, Sternorrhyncha, armored scale insect, China

\section{Introduction}

Scale insects (Hemiptera: Coccoidea) are sap-sucking parasites which are small (generally less than $5 \mathrm{~mm}$ ) and cryptic in their habitats (Gullan 1997), with at least 30 families and approximately 8000 species (García et al. 2016). Containing more than 2500 described species, Diaspididae is the largest species-rich family in the Coccoidea (García et al. 2016). Adult diaspidid females are sessile and permanently reside on their host plants (Gullan 1997). Adult females have the complete loss of the legs, the reduction of the antennae to a single segment and the modification of the abdomen into a specialized pygidium for forming the test, and these characteristics are the primary recognition features for these insects (Andersen 2010; Balachowsky 1948). Armored scale insects are important agricultural pests and have colonized a diverse set of plant species. They are distributed on every continent except Antarctica (Andersen 2010). 
Although the family classification is controversial, the Aspidiotinae and the Diaspidinae are the two major subfamilies. The genus Octaspidiotus was established as a member of the former subfamily by MacGillivray (1921), with Aspidiotus subrubescens Maskell as its type species. However, two species that he transferred from Aspidiotus are not now included in this genus. Since then, many additional species were described and added to Octaspidiotus by other authors (Borchsenius 1966; Tang 1984; Tang and Chu 1983; Takagi 1984).

Takagi (1984) showed that O. corticoides (Green) was not a member of Octaspidiotus because the distinguishing characteristics were invalid. Currently, this genus is comprised of 14 valid species, eight of which are known to occur in China (García et al. 2015; Tang 1984; Takagi 1984). There are only two species recorded from Oceania, the other 12 species being distributed throughout East Asia.

Recently, one new species of Octaspidiotus was discovered from China. It was described and illustrated in this paper, bringing the number of recognized species in the genus to 15 , of which nine species are recorded from China. A key to all known species of Octaspidiotus is provided.

\section{Materials and methods}

In this paper, the terminology described by Henderson (2011) has been used. This publication also includes illustrations for most of the species treated herein. All measurements are presented in micrometers $(\mu \mathrm{m})$. Measurements were made using NITElements D tools.

The abbreviations $\mathrm{L}_{1}, \mathrm{~L}_{2}$ and $\mathrm{L}_{3}$ are short for the median, second, and third pygidial lobes, respectively.

All specimens have been deposited in the Entomological Museum, Northwest A \& F University, Yangling, Shaanxi, China (NWAFU).

\section{Taxonomy}

\section{Genus Octaspidiotus MacGillivray, 1921}

Metaspidiotus Takagi, 1957: 35. Junior synonym.

Type species. Aspidiotus subrubescens Maskel, 1892.

Generic diagnosis. Adult female. Body is oval to rounded; derm membranous except pygidium. Cephalothorax. Antennae with 1 seta. No trilocular pores associated to the spiracles. Pygidium. With 3-4 pairs of lobes, never bilobed. Median lobes $\left(\mathrm{L}_{1}\right)$ well-developed, with notches on both margins or only present on the outer margin. Second lobes $\left(\mathrm{L}_{2}\right)$ smaller than $\mathrm{L}_{1}$, with notches on both laterals or only present on the outer lateral. Third lobes $\left(\mathrm{L}_{3}\right)$ similar to $\mathrm{L}_{2}$. Fourth lobes $\left(\mathrm{L}_{4}\right)$ small and pointed 
apically, only present in $O$. subrubescens. Marginal setae occurring on dorsal bases of $\mathrm{L}_{2}$ and $\mathrm{L}_{3}$, lanceolate, broadened and flattened. Plates are well-developed, fimbriate on the outer margin in most species, occurring laterally and even extended to the abdominal segment IV. Paraphyses absent on pygidial margin. Ducts. Dorsum has one-barred type macroducts, that are aligned in some species. Ventral microducts are scattered. Anal opening is toward the apex of the pygidium, more or less elongate. Vulvar opening situated anterior to anal opening. Perivulvar pores are quinquelocular, present or absent, if present, in four groups.

Remarks. This genus is very close to Aspidiotus Bouché, 1833 and Oceanaspidiotus Takagi, 1984 in terms of pygidial lobes and pygidium, but can be distinguished by the form of the dorsal marginal setae occurring on L1 and L2 which are lanceolate, broadened and flattened, while these setae in the other two genera are simply thickened.

\section{Octaspidiotus shanghaiensis sp. n.}

http://zoobank.org/07E3AD76-AF7A-4130-92CC-0C7895FF0A0F

Figures 1-7

Material examined. Holotype: 1 adult female: CHINA: Changfeng Park, Shanghai City, 11. IV. 2015, Hongliang Li (NWAFU).

Paratypes. 3 adult females: same data as the holotype (NWAFU).

Diagnosis. Description, $n=4$. Adult females. Field characters: adult female scale nearly oval, flat, dark greyish in colour; exuviae nearly central.

Slide-mounted: Adult female not pupillarial, 810-952 um long (holotype 905 $\mu \mathrm{m}$ long); $756-883 \mu \mathrm{m}$ wide (holotype is $881 \mu \mathrm{m}$ in the widest part of the body). Body outline oval, derm membranous except for pygidium (Figure 1). Cephalothorax. Antennae each with 1 seta (Figure 2), distance between antennae is $164.3 \mu \mathrm{m}$. Prespiracular pores absent (Figure 3). Pygidium (Figure 5). The pygidium has three pairs of lobes: $\mathrm{L}_{1}$ are well-developed, a small mesal notch is present on or near the apex, and a relative larger notch is present on or near the apex of the outer margin. $\mathrm{L}_{1}$ is 6.7-7.2 $\mu \mathrm{m}$ wide and the distance of two lobes of $\mathrm{L}_{1}$ is $1.5-2.1 \mu \mathrm{m}$ wide. Median lobes separated by a space $0.2-0.3$ times the width of $\mathrm{L}_{1} \cdot \mathrm{L}_{2}$ smaller than $\mathrm{L}_{1}$, with one notch on the outer margin. $\mathrm{L}_{3}$ similar to $\mathrm{L}_{2}$, but smaller. Lanceolate setae on $\mathrm{L}_{2}$ and $\mathrm{L}_{3}$ shorter than these lobes themselves. Plates (Figure 5 and 7) one pair of pointed plates between $\mathrm{L}_{1}$, not extending to the apex of the lobe; 2 pairs of plates between $\mathrm{L}_{1}$ and $\mathrm{L}_{2}$, apically fringed with few fine bifurcated; with 3 pairs of plates similar in size and shape between $\mathrm{L}_{2}$ and $\mathrm{L}_{3}$; with 6-7 pairs of plates lateral to L3. Ducts (Figure 4 and 5). Dorsal macroducts 1-barred-shaped. No marginal macroduct between median lobes. One marginal macroduct between $\mathrm{L}_{1}$ and $\mathrm{L}_{2}$, two between $\mathrm{L}_{2}$ and $\mathrm{L}_{3}$, and 3-4 present between L3. Dorsal submarginal macroducts about the same size as marginal macroducts which are 30-35 $\mu \mathrm{m}$ long. Total dorsal macroducts on dorsum in submarginal and marginal areas of pygidium on each side of body 32-44 (44 in holotype). Dorsal macroducts on abdomen segment IV shorter than on pygidium, with 5-6 macroducts on margin 


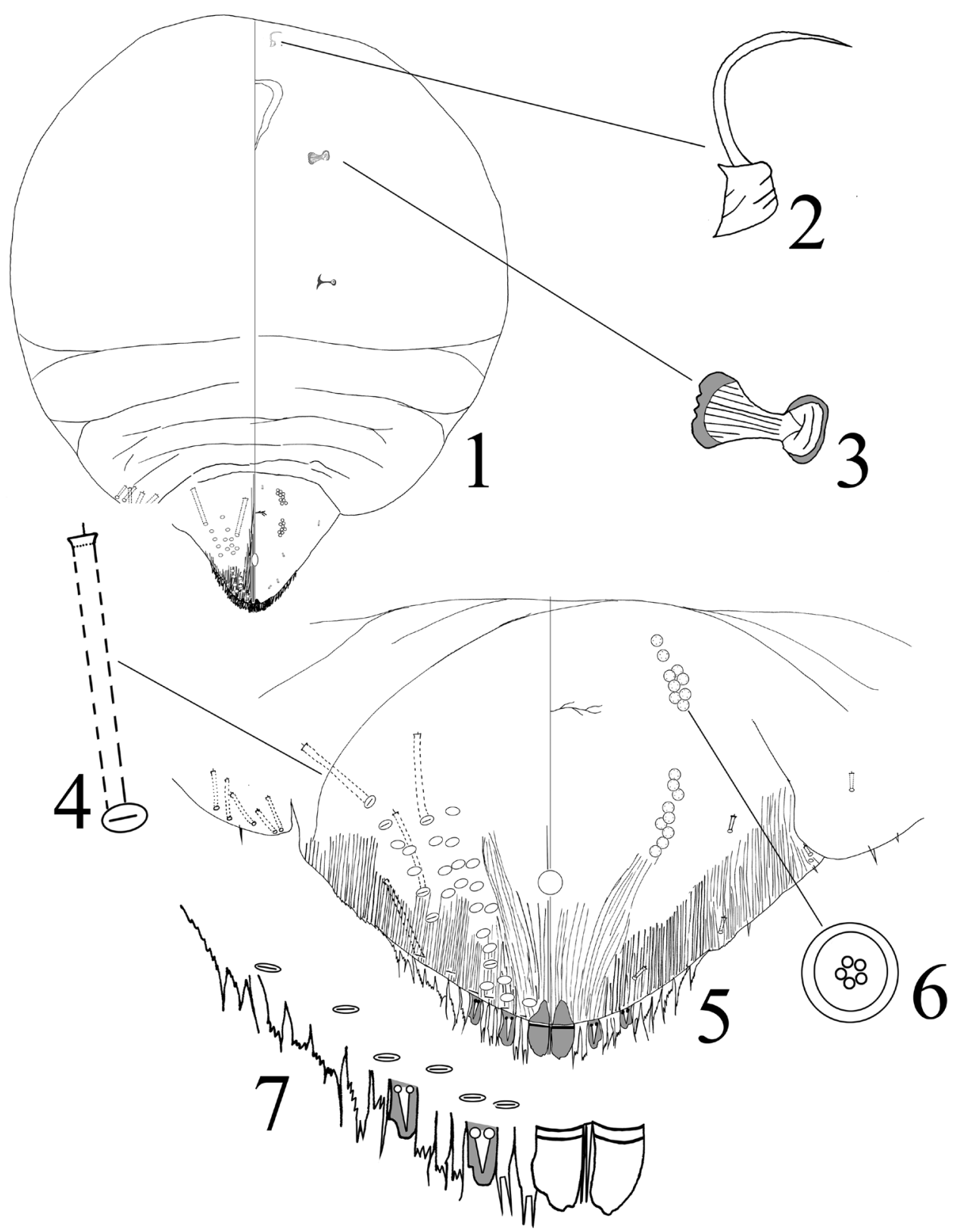

Figure I-7. Octaspidiotus shanghaiensis sp. n. adult female: I habitus $\mathbf{2}$ detail of antenna $\mathbf{3}$ detail of anterior spiracle $\mathbf{4}$ dorsal 1-barred duct $\mathbf{5}$ pygidium $\mathbf{6}$ quinquelocular pores $\mathbf{7}$ detail of the end of pygidium margin.

of abdomen segment IV. Ventral microducts are fewer and more scattered than the dorsal macroducts. Anal opening (Figure 5) 22.4-25.5 $\mu \mathrm{m}$ long in diameter, located 46.2-48.7 $\mu \mathrm{m}$ between the base of the anal opening and the base of $\mathrm{L}_{1}$. Perivulvar 
pores (Figure 5 and 6) present in an arc, divided in four groups, 9-12 anterolaterally and 8-9 posterolaterally.

Remarks. This species is similar to O. cymbidii Tang, 1984 in the body shape and the pygidial lobes, but can be distinguished by the following characters (those for $O$. cymbidii in parentheses): 1) without marginal macroduct on abdomen segment III (with $3-4$ ); 2) the three plates between $\mathrm{L}_{2}$ and $\mathrm{L}_{3}$ all equally shaped (the third plate is narrower than the first and the second plates); 3) $\mathrm{L}_{1}$ is separated by a space $0.2-0.3$ times the width of each median lobe (by a space 0.5 times the width of each $\mathrm{L}_{1}$ ); 4 ) without marginal macroducts between $\mathrm{L}_{1}$ (present).

Host. Echinochloa crusgalli (L.)

Etymology. The specific epithet is named after Shanghai, the type locality.

Distribution. China (Shanghai).

\section{Key to the adult females Octaspidiotus MacGillivray}

*denotes Chinese species

$1 \quad$ With 3 pairs lobes on pygidium, $\mathrm{L}_{4}$ absent.

- With 4 pairs lobes on pygidium, $\mathrm{L}_{4}$ present as small, pointed, sclerotized processes O. subrubescens (Takahashi) Lanceolate marginal setae occurring on dorsal bases of $\mathrm{L}_{2}$ and $\mathrm{L}_{3}$ not extending to the apex of $\mathrm{L}_{2}$ and $\mathrm{L}_{3}$, respectively....

- Lanceolate marginal setae occurring on dorsal bases of $\mathrm{L}_{2}$ and $\mathrm{L}_{3}$ more-or-less extending to the apex of $\mathrm{L}_{2}$ and $\mathrm{L}_{3}$, respectively All lobes hippocrepiform, without notches on margin of $\mathrm{L}$

O. bituberculatus Tang

Lobes normal, with notches on margin of $\mathrm{L}$

Plates between $\mathrm{L}_{1}$ bifurcate or pointed apically; distance between $\mathrm{L}_{1}$ narrower than $1 / 2$ of each lobe of $\mathrm{L}_{1}$; with 6 plates occurring lateral to $\mathrm{L}_{3}$

O. cymbidii Tang*

- Plates between $\mathrm{L}_{1}$ fringed; distance between $\mathrm{L}_{1}$ no less than $1 / 2$ of each lobe of L1; with no less than 7 plates occurring on the outer lateral to $\mathrm{L}_{3} \ldots \ldots \ldots . .7$ With notches on both margins of $\mathrm{L}_{3}$; both second and third plates between $\mathrm{L}_{2}$ and $\mathrm{L}_{3}$ narrower than first plates between $\mathrm{L}_{2}$ and $\mathrm{L}_{3}$

O. rhododendronii (Tang)

- With notches on outer margin of $\mathrm{L}_{3}$, without notches on mesal margin of $\mathrm{L}_{3}$; Second or third plates between $\mathrm{L}_{2}$ and $\mathrm{L}_{3}$ narrower than first plates between $\mathrm{L}_{2}$ and $\mathrm{L}_{3}$ 
8 Second plates between $\mathrm{L}_{2}$ and $\mathrm{L}_{3}$ narrower than first and third plates between $\mathrm{L}_{2}$ and $\mathrm{L}$

- $\quad$ Third plates between $\mathrm{L}_{2}$ and $\mathrm{L}_{3}$ narrower than first and second plates between $\mathrm{L}_{2}$ and $\mathrm{L}$ O. yunnanensis (Tang \& Chu)

9 With 22-24 perivulvar pores and 35-42 dorsal macroducts on pygidium .... O. tamarindi (Green)

- With 43-60 perivulvar pores and 54-65 dorsal macroducts on pygidium .... With notches on mesal margin of $\mathrm{L}_{2}$; distance between $\mathrm{L}_{2}$ and $\mathrm{L}_{3}$ equal to $1 / 5$ of each lobe of L1; plates between $\mathrm{L}_{1}$ bifurcate or pointed apically.....

O. shanghaiensis sp. n.

- With notches on both margins of $\mathrm{L}_{2}$; distance between $\mathrm{L}_{2}$ and $\mathrm{L}_{3}$ more than $1 / 3$ of each lobe of $L_{1}$; plates between $L_{1}$ fringed.......................................11

11 Body strongly sclerotized at maturity .................................................12 Body remaining membranous O. nothopanacis (Ferris)

12 Number of perivulvar pores less than 30; with 7 plates occurring on the outer side of $\mathrm{L}$ O. stauntoniae (Takahashi)

- Number of perivulvar pores more than 30; with 8 plates occurring on the outer side of $\mathrm{L}_{3}$ O. calophylli (Green)

13 With notches on outer margin of $\mathrm{L}_{2}$ and $\mathrm{L}_{3}$; with no more than 7 plates occurring on the outer side of $\mathrm{L}_{3}$ O. pinicola (Tang)*

- With notches on both margin of $\mathrm{L}_{2}$ and $\mathrm{L}_{3}$; with no less than 8 plates occurring on the outer side of $\mathrm{L}_{3}$ 14

14 With more than 80 dorsal macroducts and 32-47 perivulvar pores O. multipori (Takahashi)

- With less than 80 dorsal macroducts and 23-29 perivulvar pores O. machili (Takahashi)

\section{Acknowledgements}

This study is supported by the National Natural Science Foundation of China (Grant No. 31301899 and No. 31501876) and Shanxi Agricultural University of Science and Technology innovation fund projects (2015YJ03).

\section{References}

Andersen JC, Wu J, Gruwell ME, Morse GE, Santana S, Feliciano N, Gwiazdowski RA, Normark BB (2010) A phylogenetic analysis of armored scale insects, based upon nuclear, mitochondrial, and endosymbiont gene sequences. Molecular Phylogenetics and Evolution 57: 992-1003. doi: 10.1016/j.ympev.2010.05.002 
Balachowsky AS (1948) Les cochenilles de France, d'Europe, du nord de I'Afrique et du basin Méditerranéen. IV. Monographie des Coccoïdea, classification-Diaspidinae (Premïre Partie). Actualités Scientifigues et Industrielles 1054: 243-394.

Borchsenius NS (1966) [A catalogue of the armoured scale insects (Diaspidoidea) of the world]. Nauka, Moscow \& Leningrad, 449 pp. [In Russian]

García M, Denno B, Miller DR, Miller GL, Ben-Dov Y, Hardy NB (2015) ScaleNet: A Literature-based model of scale insect biology and systematics. http://scalenet.info [accessed: 2015]

Gullan PJ, Kosztarab M (1997) Adaptions in scale insects. Annual Review of Entomology 42: 23-50. doi: 10.1146/annurev.ento.42.1.23

MacGillivray AD (1921) The Coccidae. Tables for the Identification of the Subfamilies and Some of the More Important Genera and Species, Together with Discussions of Their Anatomy and Life History. Scarab, Urbana, 502 pp. doi: 10.5962/bhl.title.21115

Tang FT (1984) The scale insects of horticulture and forests of China. Shanxi Agricultural University Press Research Publication 2: 1-115. [In Chinese]

Tang FT, Chu CY (1983) Three new species of Diaspididae from Keteleeria evelyniana in vicinity of Kunming, Yunnan. Acta Zootaxonomica Sinica 8: 301-306. [In Chinese]

Takagi S (1984) Some aspidiotine scale insects with enlarged setae on the pygidial lobes (Homoptera: Coccoidea: Diaspididae). Insecta Matsumurana (New Series) 28: 1-69. 